\title{
Innovation in justice: co-production, competence and user satisfaction in judicial mediation
}

\author{
Janaina Angelina Teixeira 1 \\ Mariana Carolina Barbosa Rêgo ${ }^{2}$ \\ Antonio Isidro da Silva Filho ${ }^{3}$ \\ 1 Universidade de Brasília / Programa de Pós-Graduação em Educação, Brasília / DF — Brazil \\ 2 Instituto Federal de Brasília, Brasília / DF - Brazil \\ ${ }^{3}$ Universidade de Brasília / Programa de Pós-Graduação em Administração, Brasília / DF — Brazil
}

This study evaluated the effects of co-production and the mediator's competence on the results of Judicial Mediation in the Court of Justice of the Brazilian Federal District and Territories. Data was collected using satisfaction surveys applied to the parties using the court's judicial mediation services. The sample refers to the period from January 2013 to July 2015, totaling 312 participants and 107 discursive answers. The evaluation adopted techniques of descriptive statistics, exploratory factor analysis, and logistic regression as well as content analysis. The results showed that the only statistically significant variable was the mediator's competence, which increases the likelihood of positive perception about the outcomes of judicial mediation both for citizens and the justice system. Both parties using the services did not perceive that co-production affects the outcomes. This result was due to the complexity of the cases mediated, which makes it hard to observe the role of cooperation in achieving the outcomes. For the citizen, the mediator is primarily responsible for directing the judicial mediation procedure as well as the outcomes achieved through the procedure. We provide recommendations and a research agenda aimed at strengthening research in the area.

Keywords: co-production of public services; innovation in public services; court; judicial mediation.

\section{Inovação no Judiciário: coprodução, competências e satisfação do usuário na mediação judicial}

O presente estudo teve por objetivo testar os efeitos da coprodução e das competências do mediador nos resultados da mediação Judicial no Tribunal de Justiça do Distrito Federal e Territórios - TJDFT, com base na Pesquisa de Satisfação do Usuário - PSU, aplicada pelo TJDFT às partes usuárias dos serviços de mediação judicial. Os dados analisados correspondem à amostra tabulada no período de janeiro de 2013 a julho de 2015, totalizando 312 participantes e 107 respostas discursivas. Os objetivos propostos foram alcançados a partir de técnicas de estatística descritiva, análise fatorial exploratória e regressão logística, além de análise de conteúdo. Por meio dos testes realizados foi constatado que a única variável que apresentou significância estatística foi a de competências do mediador, comprovando-se que as competências do mediador aumentam a probabilidade de percepção positiva dos resultados da Mediação Judicial para o usuário do serviço e para o Judiciário. Tem-se ainda, que a coprodução não pode ser percebida como um fator que impacta nos resultados do serviço para o cidadão e para o judiciário. Esse resultado se deu devido à complexidade dos casos mediados, o que faz com que a percepção de cooperação para se chegar a um resultado seja de difícil observação. Por conseguinte, observa-se que para o cidadão, o mediador é o principal responsável pelo direcionamento do procedimento de mediação judicial, bem como pelos resultados alcançados com o procedimento. Ao final do estudo foram elencadas recomendações e agenda de pesquisa, com vistas ao fortalecimento de pesquisas na área.

Palavras-chave: coprodução de serviços públicos; inovação em serviços públicos; judiciário; mediação judicial. 


\section{Innovación en el Poder Judicial: coproducción, competencias y satisfacción del usuario en la mediación judicial}

Este estudio evaluó los efectos de la coproducción y las competencias de los mediadores en los resultados de la mediación judicial en el Tribunal de Justicia del Distrito Federal y Territorios. Los datos se recopilaron a través de encuestas de satisfacción de los usuarios realizadas por el Tribunal a los usuarios de los servicios de mediación judicial. La muestra se refiere al período comprendido entre enero de 2013 y julio de 2015, con un total de 312 participantes y 107 respuestas discursivas. La evaluación se realizó mediante técnicas de estadística descriptiva, análisis factorial exploratorio y regresión logística, así como análisis de contenido. Se constató que la única variable estadísticamente significativa era la competencia del mediador, lo que aumenta la probabilidad de una percepción positiva de los resultados de la mediación judicial para el usuario del servicio y el Poder Judicial. También se observó que la coproducción no se percibe como un factor que afecta los resultados del servicio para los ciudadanos o el Poder Judicial. Este resultado se debió a la complejidad de los casos mediados, lo que hizo que la percepción de cooperación para llegar a un resultado sea difícil de observar. Consiguientemente, para el ciudadano, el mediador es el principal responsable de dirigir el procedimiento de mediación judicial, así como de los resultados logrados a través del procedimiento. Finalmente, se enumeran recomendaciones y una agenda de investigación para fortalecer la investigación en el área.

Palabras clave: coproducción de servicios públicos; innovación en servicios públicos; poder judicial; mediación judicial.

\section{INTRODUCTION}

Co-production for the production of public services is relatively new and began with New Public Management in the 1970s (Torfing, 2013). This way of thinking public service suggested a new conception of the way society organizes itself by taking citizens from passive agents to active agents in the production of services (Gallouj, 2002).

Although this orientation is considered an innovative process, it has not been much explored in the literature. For example, of the total of 163 articles found by Mustak, Jaakkola, Halinen (2013) in their literature review research on the participation of the user of service for value creation, with a 40-year time-cut, only 4 articles had as their locus public sector.

According to Chen, Tsou, and Ching (2011), co-production significantly influences service innovation due to changes in service interaction patterns provided by the role of providers, co-producers and users (Ostrom et al., 2010). The Collaborative practices and interaction in production processes open up new learning opportunities and discoveries, and collaboration also enables each partner to contribute to improving production processes. It is noteworthy that the area of public services needs a constant flow of innovations is maintained, as it is essential to sustain the improvement in the provision of these services (Albury, 2005).

In this sense, considering the lack of research on the phenomenon in many countries, empirical studies are necessary for the development of innovations in public administration (Koch \& Hauknes, 2005). Although in recent years there has been a significant increase in publications on innovations in the Brazilian judiciary, there are still few studies that favor a more quantitative and explanatory orientation are still scarce (Sousa \& Guimarães, 2014).

It should the slowness of the Brazilian Judiciary System (Sadek, 2004; Stumpf, 2009; Vieira \& Pinheiro, 2008) stands out, that makes the system to present barriers to innovation. Given that the 
judiciary's main task lies in conflict resolution, the lengthy time in coercively resolving conflicts results in detrimental consequences for society, including the ineffectiveness of judicial protection and negative impacts on the country's economy (Vieira \& Pinheiro, 2008). This increasing judicial demand causes the need to develop new instruments to meet the needs of society, one of them is judicial mediation.

Judicial mediation is a technical activity exercised by an impartial third party without decisionmaking power, which, chosen or accepted by the disputing parties, helps and encourages the identification or development of consensual solutions (Law 13.140/2015). In the activities of judicial mediation the co-production occurs as the mediator acts as a facilitator using techniques aimed at a joint solution to the conflicts, in which the parties are satisfied and their social relationship can continue (Azevedo, 2015).

Co-production and innovation provide dialogue and interaction that generates, in the end, product enrichment as well as the perception of value by the user. The mediator is an essential figure in the process of mediation, being the conductor of all action. Morais Sales and Chaves (2014) state that for mediation to succeed, two aspects are necessary: the mediator's qualification (extrinsic qualities) and the mediator's profile (intrinsic qualities). Thus, the mediator needs to be qualified to enable the parties involved to get to the root of the conflict, leaving their positions, to achieve the real interests and values (Warat, 2001) and must have in their profile characteristics such as the ability to assist and stimulate cooperation, active listening, creativity to assist people in meeting the converging points in conducting a satisfactory solution (Morais Sales \& Chaves, 2014, p. 266).

Considering judicial mediation as an innovative mechanism that seeks to provide access to justice and speed in judicial decisions, this research seeks to answer the following question: What are the effects of co-production and mediator competence on the results of judicial mediation in TJDFT?"

The aim of this study was to test the effects of co-production and mediator competence on judicial mediation outcomes in the Court of Justice of the Federal District and Territories (TJDFT). We adopted the following specific aims: (a) verify the validity of the satisfaction survey developed by TJDFT; (b) empirically test the relationship between the perception of co-production, mediator competence, tangible and intangible characteristics of the service, and Judicial Mediation outcomes for both service users and (c) for members of the Court.

\section{INNOVATION THROUGH THE INTEGRATIVE APPROACH}

The integrative approach to innovation aims to synthesize tangible and intangible goods, without emphasizing the separation between services and industry (Gallouj, 2007). Thus, innovation is the reproducible addition of new elements or combinations of existing elements, resulting in innovative solutions or forms of service delivery (Sundbo \& Gallouj, 1998).

The integrative approach proposes a novel taxonomy of innovation based on a new product vision (Gallouj \& Savona, 2009). From this perspective, a product is a set of tangible and intangible characteristics that depends on the interaction between service providers and users in a particular market (Gallouj \& Weinstein, 1997; Gallouj, 2002; Hauknes, 1998; Sundbo \& Gallouj, 1998).

This approach takes into account the provision of services such as simultaneous mobilization of technical characteristics (tangible and intangible) and internal and external expertise in the production 
of service attributes (Gallouj \& Weinstein, 1997; Gallouj, 2007). It is inferred that innovation is replaced by a broader notion, since the service sector is characterized by its fluidity and intensive interactions between service providers and users, which motivates innovation through an interactive construction of concepts (Vargas, 2006).

Based on the propositions of the integrative approach, Gallouj and Weinstein (1997) developed a model based on service attributes characterized into four vectors [C], [C'], [X], [Y]. This model was revised by Gallouj and Savona (2010) who categorized technical service characteristics as either internal or external. Thus, the conceptual model was then made up of five vectors [C] [C '], [T], [T'] and [Y].

According to this model, vectors $[\mathrm{C}]$ and $\left[\mathrm{C}^{\prime}\right]$ represent the interface of the services and are characterized as competences respectively of the service provider or user / client. Fleury and Fleury (2001, p. 188) assert that individual competence consists of a "recognized know how to act responsibly, which means mobilize, integrate, transfer knowledge, resources, and skills that add economic value to the organization and social value for the individual". According to the Judicial Mediation Manual, a competent mediator is one who can develop the ability to consistently and ethically apply a collaborative approach (Azevedo, 2015).

The vector [T] signifies internal technical characteristics and the vector [T'] indicates external technical characteristics. Innovation happens when the technical characteristics of the service or competence undergo change. The vector $[\mathrm{Y}]$ is related to the characteristics of the service, use values, and applications that the service has. Subsequently the model was expanded by Djellal, Gallouj, and Miles (2013), who added relationships between the vectors ([C']-[Y]) and ([C']-[T]). Figure 1 illustrates the relationship between the model vectors.

\section{FIGURE 1 THE PRODUCT AS THE CONJUNCTION OF VECTORS OF CHARACTERISTICS AND} COMPETENCES

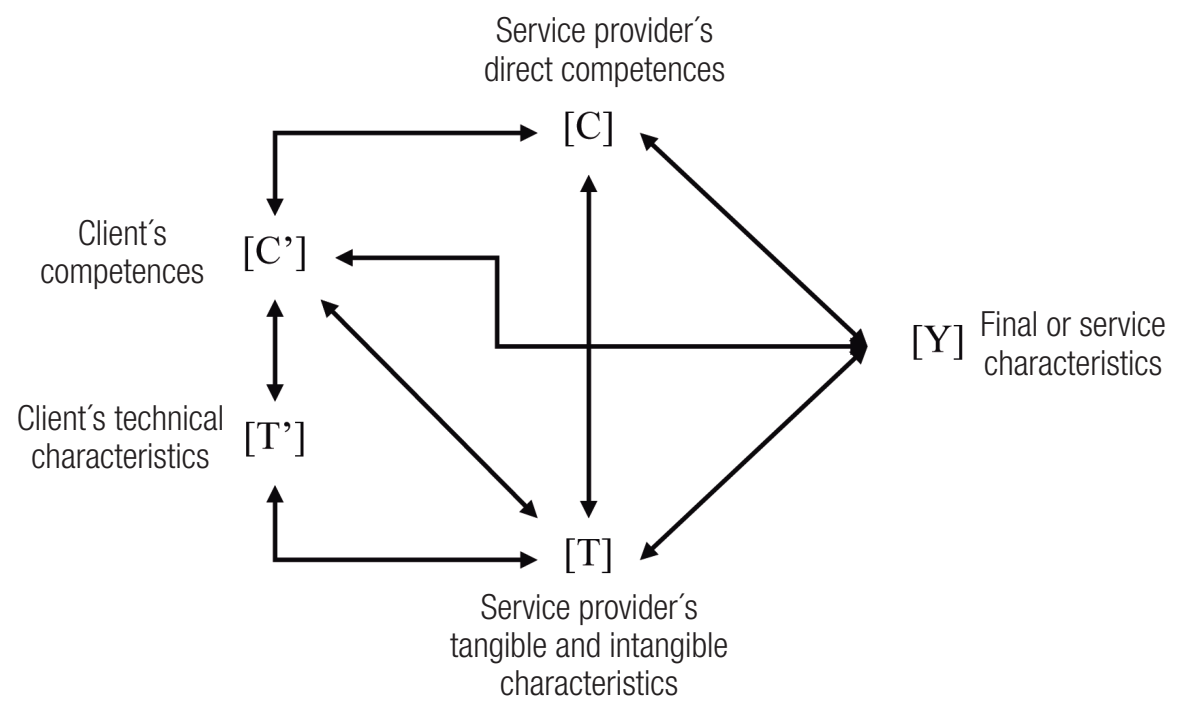

Source: Adapted from Djellal et al. (2013). 
According to the model shown in Figure 1, innovation is categorized into five types, namely: radical innovation, improvement, incremental, recombination, and formalization. The definition of each type is the result of analysing different combinations of vectors that characterize the production of a service. The scheme proposed by the authors provides a conception of innovation dynamics, allowing an in depth analysis of forms of innovation or innovation models that describe the particular characteristics of the interactions $[\mathrm{C}],\left[\mathrm{C}^{\prime}\right],[\mathrm{T}],\left[\mathrm{T}^{\prime}\right]$, and $[\mathrm{Y}]$.

The integrative approach supports the implementation of innovation theories without a dichotomy between goods and services, according to current circumstances in an organization or area of study (Vargas, 2006). Therefore, court mediation, the subject of this study, as an innovative service, is homologous, due to the integrative structure of its procedures and the relationship with the user, with the integrative approach to innovation, embracing different service characteristics and the interactive nature of the co-production of services.

\section{INNOVATION IN PUBLIC JUSTICE SERVICES WITH EMPHASIS ON CONFLICT RESOLUTION}

Public sector innovation is the creation and implementation of new processes, products, services, and delivery methods that result in significant improvements in the efficiency, efficacy, and quality of outcomes (Albury, 2005). Corroborating this view, Halvorsen, Hauknes, Miles, and Roste (2005), believe that innovation in the public sector should be studied in broader terms as behavioral change. They also advocate the idea that a factor restricting research into innovation dynamics in public institutions is the complex relationships inside own public sector, involving the need for caution in the analysis of change and innovation.

The Brazilian Court shows critical signs of being sustained by a cumbersome infrastructure with limited efficiency, where the ineffectiveness of a coercive form of conflict resolution results in harmful social consequences, including ineffective judicial representation and negative economic outcomes for the country (Vieira \& Pinheiro, 2008). This judicial sentence culture consumes increasing amounts of resources, as well as frequent delays, in the High Courts and the Supreme Court. It also increases the number of judicial executions (Watanabe, 2005).

However, a growing number of lawsuits necessitate the development of new means to meet social demand. A milestone in the Judicial Reform, implemented by the National Council of Justice (CNJ) was the enactment of Resolution 125, which deals with conflicts of interest in the context of the Court for National Judicial Policy. Judicial mediation is envisaged in the Mediation Law and in the New Civil Procedure Code (Article 165) and the mediation should be practiced as a form of social peace and not just conflict resolution, in view of mediated social relations (Watanabe, 2005).

\section{CO-PRODUCTION OF PUBLICS SERVICES}

Co-production through the interaction of citizens and government increases the quality of services provided and suggests a new concept of social organization, leading citizens from being passive to becoming active agents of service provision (Brudney \& England, 1983). For Gallouj (2002) the term co-production indicates situations in which interaction, essentially operational, is intensive and balanced, and may occur through relationships that involve users and providers. Co-production can also be 
understood as a joint activity between the organization and user to generate outcomes that collectively represent the creation of a specific value for the citizen, in which the relationship between the user and the government (provider) is more important than the transaction itself. This is because a vision focused on the service is participatory, integrated, and dynamic, with the service being the optimized result of an interactive learning process between organization and citizen (Vargo \& Lusch, 2004).

The active involvement of users and providers is essential for the success of judicial mediation, given the assumption of a collective construction of the resolution using non-adversarial methods. The collaborative approach is characterized by direct communication between the parties, with or without the assistance of a facilitator, called the mediator or conciliator. The prerogative of decisionmaking is shared and parties seek to integrate interests, increasing the chances of reaching a satisfactory outcome (Passani, Corrêa, \& Bastos, 2014). Thus, the production of services is often the result of a joint effort between the service provider and user. In this process of co-production, the quality of service / product obtained depends largely on the nature of the interaction between the parties and the quality of the communication process involved (Hertog, 2000).

Citizen participation in the conception and evaluation of public services has become increasingly important, because the interaction between the service provider and user have an impact on the perceptions of the final value of the service. Co-production affects an organization's outcomes, increasing productivity, reducing costs, and customizing services on offer, amongst other benefits (Lusch, Vargo, \& O’Brien, 2007; Chen et al., 2011).

Co-production associated with innovation promotes continuous contact with users, highlighting insights and delivery, and facilitating the success of innovations (Chen et al., 2011). User participation is associated with improved quality and greater perceived value because it gives the user a voice in the management of the co-production process. The more information users have, the more effective their participation, and the greater the value of the final outcome of the service (Mustak et al., 2013).

Kelly (2005) argues that the evaluation of the user and the service provided generates public sector efficiency. Therefore, it is not enough to simply evaluate the service. It is also necessary that the results of evaluation be assimilated by the organization and the citizen as a means of service improvement. It is evident that users are more likely to collaborate with the assessment of service satisfaction when there is a relationship of cooperation and commitment with the provider (Shim, Sheu, Chen, Jiang, \& Klein, 2010).

From the standpoint of users of services provided by public administration, research suggests that people are not only interested in the final outcome of the services, but also in their experience during delivery. The experience of the user of the service is fundamental to their perception of satisfaction (Osborne, 2013). The involvement of the user in service development can generate a more far-reaching assessment of the necessary improvement, thereby increasing the experience of the service.

\section{THEORETICAL PREMISES AND HYPHOTESES}

For this study certain premises were considered. The first is that relationships between the competences of the provider/mediator [C], co-production with litigants (service users) [C'], and tangible and intangible characteristics of service provision $[\mathrm{T}]$ affect the overall quality of services for the citizen $[\mathrm{YC}]$. The second premise is that the relationship between $[\mathrm{C}]-\left[\mathrm{C}^{\prime}\right]-[\mathrm{T}]-[\mathrm{YC}]$ impacts overall service 
outcomes for the Court [YJ]. Notably, in the vector scheme proposed by Gallouj $(2002,2007)$ and Gallouj and Weinstein (1997), which characterizes the service product, the vector [C'] generally refers to user competence. For the model used in this research however, the vector [C'] signifies user coproduction for production of overall service outcomes.

Service providers' competences are mobilized to generate final service characteristics (Gallouj, 2007). Zainuddin, Russell-Bennett, and Previte (2013) state that the quality of the technical skills of the service provider, such as specialization of staff, can impact the perception of the quality of service outcomes on the part of users.

Djellal et al. (2013) state that the competence vector should also reflect social and civic competences, which represent the ability to provide a service or to maintain a relationship with the user, who is often in a vulnerable situation.

Assuming that mediation is a procedure co-produced by the mediator [C] and service users [C '], or litigants, the following hypotheses are presented:

Hypothesis 1 - A positive perception of mediator competence increases the likelihood that the user will have a positive perception of judicial mediation outcomes;

Hypothesis 2 - A positive perception of mediator competence increases the likelihood that the Court will have a positive perception of judicial mediation outcomes.

The third and fourth hypotheses are related to the co-production of the litigants [C']. According to the literature review on co-production, dialogue and interaction promote the delivery of personalized services, generating enrichment of the final product as well as the perceived value for the user (Chen et al., 2011; Vargo \& Lusch, 2004). Co-production affects the results of the organization through increased productivity, cost reduction, and customization of services (Lusch et al., 2007; Chen et al., 2011). In this context, are present the following hypothesis:

Hypothesis 3 - Co-production increases the likelihood that the service user will have a positive perception of the outocomes of the judicial mediation service.

Hypothesis 4 - Co-production increases the likelihood that the Court will have a positive perception of judicial mediation outcomes.

The fifth and sixth hypotheses relate to the effects of vector [T], the tangible and intangible technical features of the service, for production of the final attributes of the service [YC, YJ]. Hence, the following hypotheses are presented:

Hypothesis 5 - Tangible and intangible characteristics of service provision increase the likelihood that the user will have a positive perception of the outcomes of judicial mediation;

Hypothesis 6 - Tangible and intangible characteristics of service provision increase the likelihood that the Court will have a positive perception of the outcomes of judicial mediation.

Finally, an additional hypothesis aims to test the possible effects of the results for the Court [YJ], in view of the perception of results by the citizen/user [YC]. The hypothesis is the following:

Hypothesis 7 - A positive perception of the service outcomes on the part of the user increases the likelihood that the Court will have a positive perception of the results.

According to the theoretical basis of this study and the hypotheses presented, the theoretical model developed for the study can be see in Figure 2. We also used the following identification variables: type of action (civil, family) and respondents (claimants, defendants). 


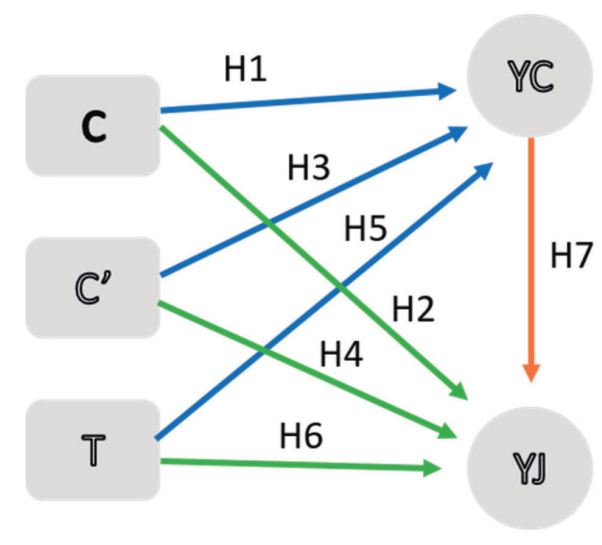

Source: Elaborated by the authors.

\section{METHOD}

After presenting the descriptive statistics of the sample, two data analysis steps are undertaken, one exploratory and the other explanatory. Data for this study is from the User Satisfaction Instrument (USI) applied by TJDFT with users of the Judicial Mediation Service. The instrument was constructed by the Permanent Center for Mediation and Conciliation (NUPEMEC of the TJDFT) in 2012 and implemented in 2013. The study was conducted with a sample taken between January 2013 and July 2015.

Data collection was carried out with volunteers from users of the judicial mediation service. At the conclusion of mediation litigants were invited to fill out the evaluation. After completing the evaluation, they were requested to deposit the research surveys in booths located in the reception area, to ensure the fairness of the procedure. The surveys were forwarded to the NUPEMEC, which carried out the processing and preparation of quarterly reports (TJDFT, 2013). The instrument consists of 26 quantitative and 2 qualitative items. The initial sample had a total of 880 responses, of which 264 contained inconclusive answers and 304 had a large amount of missing data. These 568 responses were removed from the database. The total sample was 312 complete responses.

The descriptive analysis of the data aimed to describe the sample, and identify possible patterns for extreme cases (Hair, Black, Babin, Anderson, \& Tatham, 2009; Tabachnick \& Fidell, 2007). To identify atypical univariate cases (outliers) the box-plot was used and for multivariate cases the Mahalanobis distance was used, as suggested by Tabachnick and Fidell (2007). With the removal of extremes cases from the set, the sample lost variance, which meant that that the statistical tests were ran with the outliers.

Of the 312 respondents, 82 (26.2\%) correspond to mediations carried out in the forum in Brasilia. Of these 54 were civil judicial mediations, and 28 were in the family area. As for the Taguatinga forum, there were 230 cases $(73.8 \%)$, of which 122 were civil suits and 108 family suits. The sample had responses of 194 (62.2\%) claimants and 118 (37.8\%) defendants. 
In the first exploratory stage of analysis, we used exploratory factor analysis to test the validity of the instrument developed by TJDFT, provide verification of the behavior of the variables, to define the inherent structure of variables and identify factors composed of strongly interrelated variables (Hair et al., 2009). The second phase consisted of a mixed phase in which we employed qualitative and quantitative methods. In the quantitative phase, the study used logistic regression.

In the qualitative phase, the chosen method was content analysis, in order to understand the content of messages through communication analysis techniques that uses systematic procedures and objective description of message content. Thus, the analysis was conducted based on three criteria: pre-analysis, exploration of the material with the definition of a posteriori categories and treatment of the results (Bardin, 2009). The 107 comments of the discursive question that compose the research were analysed. After the pre-analysis the answers were classified into 4 categories: mediator skills [C], co-production [C'], material and immaterial characteristics of service delivery $[\mathrm{T}]$, and results [YC and YJ] in content analysis We chose to maintain the results category in general, making the differentiations of the extracts found in the category itself.

\section{RESULTS}

The validity of the questionnaire constructed by the TJDFT was tested using the results of exploratory factor analysis of the items of the User Satisfaction Instrument (USI). The analysis was run using the principal axis factoring (PAF), with orthogonal rotation (varimax), which allows the correlation of the vectors adopting a constant value (Field, 2009). By investigating the KMO statistic (Kaiser-Meyer-Olkin), it was possible to identify the factor composition of the instrument. The statistical criteria considered in the selection of the number of factors was the Eigenvalues over 1, the factor loadings greater than 0.4 (Field, 2009) and Cronbach's alpha to measure the reliability of the factors.

The exploratory factor analysis resulted in five factors: Factor 1 Competence of the mediator (alpha 0.897; factor loadings: 0.826-0.555); Factor 2 Tangible and intangible characteristics of the service provision (alpha 0.785; factor loadings: 0.833-0.614); Factor 3 Co-production between the litigants (alpha 0.898; factor loadings 0.897-0.868); Factor 4 Results for the Court (alpha 0.647; factor loadings 0.887-0.677); and, Factor 5 Results for the citizens (alpha 0.657; factor loadings $0.847-0.811$ ). The KMO was of 0.840 , the Cronbach's alpha was 0.841 and the model explained $66 \%$ of the total variance.

The results of the empirical models tested using logistic regression are presented below, as well as the results of the content analysis. The logistic regression was carried on the five factors identified by the exploratory factor analysis, through the stepwise forward LR method.

The first model tested was with the dependent variable results for the citizen [YC] and the independent variables [C]-[C']-[T]. Five empirical models were generated to test hypotheses H1, H3 and H5: total, civil, family, claimants and defendants. The results showed that the variable Competence of the mediator was statistically significant in four of the five models tested, being the only variable that remained in the models. In other words, the positive perception of mediator competence increases the probability of a positive perception of the results of the judicial mediation for the service user. 


\begin{tabular}{|c|c|c|c|c|c|}
\hline Variables in the Model & B & Wald & Sig. & $\operatorname{Exp}(B)$ & I.C. $(95 \%)$ \\
\hline & & Total & & & \\
\hline \multirow[t]{2}{*}{ Competence of the mediator } & 0.389 & 8.596 & 0.003 & 1.475 & $1.138-1.913$ \\
\hline & & Civil & & & \\
\hline \multirow[t]{2}{*}{ Competence of the mediator } & 0.333 & 5.463 & 0.019 & 1.395 & $1.055-2.048$ \\
\hline & & Claimants & & & \\
\hline \multirow[t]{2}{*}{ Competence of the mediator } & 0.414 & 4.015 & 0.045 & 1.513 & $1.009-2.269$ \\
\hline & & Defendants & & & \\
\hline Competence of the mediator & 0.400 & 5.242 & 0.022 & 1.492 & $1.059-2.103$ \\
\hline
\end{tabular}

Source: Field research.

Note: General: Nagelkerke R²: 0.049; Prediction: 88.8\%; Civil: Nagelkerke ${ }^{2}$ : 0.034; Prediction: 91.5\%; Claimants: Nagelkerke R²: 0.082; Prediction: 94.1\%; Defendants: Nagelkerke $\mathrm{R}^{2}$ : 0.084; Prediction: $87.1 \%$.

For Model Test 2 the dependent variable was Results for the Court [YJ] and independent variables $[\mathrm{C}]-\left[\mathrm{C}^{\prime}\right]-[\mathrm{T}]-[\mathrm{YC}]$. Five empirical models were generated to test hypotheses H2, H4, H6 and H7: total, civil, family, claimants and defendants. The results show that the competence of the mediator was statistically significant in all of the five models tested, once again being the only variable that remained in the models. Thus, the positive perception of mediator competence increases the probability that the perception of the results of the judicial mediation will be positive for the Court.

\section{TABLE 2 LOGISTIC REGRESSION OF THE EMPIRICAL MODELS GENERATED BY TEST 2}

\begin{tabular}{|c|c|c|c|c|c|}
\hline Variables in the Model & B & Wald & Sig. & $\operatorname{Exp}(B)$ & I.C. $(95 \%)$ \\
\hline & & Total & & & \\
\hline \multirow[t]{2}{*}{ Competence of the mediator } & 0.597 & 16.291 & 0.000 & 1.817 & $1.359-2.428$ \\
\hline & & Civil & & & \\
\hline \multirow[t]{2}{*}{ Competence of the mediator } & 0.419 & 7.587 & 0.006 & 1.520 & $1.128-18.362$ \\
\hline & & Family & & & \\
\hline \multirow[t]{2}{*}{ Competence of the mediator } & 1.426 & 13.883 & 0.000 & 4.163 & $1.966-8.816$ \\
\hline & & Claimants & & & \\
\hline \multirow[t]{2}{*}{ Competence of the mediator } & 0,768 & 11,379 & 0,001 & 2,155 & $1,379-3,366$ \\
\hline & & Defendants & & & \\
\hline Competence of the mediator & 0,482 & 6,878 & 0,009 & 1,619 & $1,129-2,321$ \\
\hline
\end{tabular}

Source: Field research.

Note: General: Nagelkerke R²: 0.120; Prediction: 91.7\%; Civil: Nagelkerke $\mathrm{R}^{2}$ : 0.210; Prediction: 85.4\%; Family: Nagelkerke R²: 0.296; Prediction: 89.8\%; Claimants: Nagelkerke R²: 0.128; Prediction: 89\%; Defendants: Nagelkerke R²: 0.124; Prediction: 92.3\%. 
The content analysis was conducted based on the answers from a space at the end of the form where service users can leave suggestions, complaints, compliments and feedback for the service as a whole. From the analysis, it was possible to identify four categories that converge with the empirical results found: competence of the mediator [C], co-production [C'], tangible and intangible characteristics of the service $[\mathrm{T}]$ and mediation results [YC and $\mathrm{YJ}]$.

The results for all the categories found are presented in Box 1. The perception of the participants of this study for the category Competence of the mediator were positive, emphasizing the quality of the service delivered by the mediator. In terms of the category Co-production, it is relevant to note aspects related to the collaborative approach, since the litigants recognize the need to listen each other and to look for a solution that meets the needs of both parties. Critical factors are related to the perceived lack of collaboration of the other party involved in the conflict. There is also a subcategory associated with the co-production with the mediator/service provider that shows the perception that co-production, in judicial mediation services, is based on the mediator's activities. The category of the tangible and intangible characteristics of the service provision enhances the quality of the service and the Court infrastructure, but the litigants complained about the accessibility of the Courts. Lastly, the category Results of the mediation is divided in positive aspects for the citizen and the Court and critical factors for both subdivisions.

BOX 1

CONTENT ANALYSIS OF THE ANSWERS OF THE LITIGANTS

\begin{tabular}{|c|c|c|}
\hline \multicolumn{3}{|r|}{ Category: Competencies of the mediator } \\
\hline Subcategories & Frequency & Evidence \\
\hline Positive aspects & 32 & $\begin{array}{l}\text { "The mediator demonstrated ability to handle the matter being discussed...". } \\
\text { "The mediator did a great job, respecting common sense. The litigants decided on a } \\
\text { settlement that benefited the minors involved in the conflict the best". } \\
\text { "I would like to thank the mediator for her competence and great job, even though this } \\
\text { conflict did not end in a settlement. Congratulations to everyone involved". }\end{array}$ \\
\hline Critical aspects & 2 & $\begin{array}{l}\text { "I suggest that the mediator has access to the legal process before the mediation, so he } \\
\text { can have a better understanding of the case in question". } \\
\text { "Further elucidation in the beginning of the mediation was needed". }\end{array}$ \\
\hline \multicolumn{3}{|r|}{ Category: Co-production } \\
\hline Subcategories & Frequency & Evidence \\
\hline Positive aspects & 9 & $\begin{array}{l}\text { "This mediation was really worth it for me. I learned that we need to listen to the other } \\
\text { side more carefully". } \\
\text { "I believe that everything that happened here will really improve the relationship between } \\
\text { the parties involved in the legal process". }\end{array}$ \\
\hline Critical aspects & 4 & $\begin{array}{l}\text { "In this case, the mediation was not possible thanks to the other party. I do not think it } \\
\text { was adequate to come if the defendant was not ready or open to negotiate". }\end{array}$ \\
\hline $\begin{array}{l}\text { Co-production } \\
\text { with the mediator/ } \\
\text { service provider }\end{array}$ & 4 & $\begin{array}{l}\text { "The role of the 'A' and 'B' mediators... The ability of the mediators was exceptional and } \\
\text { exceeded all the expectations". } \\
\text { "The mediator did a great job regarding the common sense necessary for us to decide on } \\
\text { a settlement that was best for our children". }\end{array}$ \\
\hline
\end{tabular}




\begin{tabular}{|c|c|c|}
\hline \multicolumn{3}{|r|}{ Category: Tangible and intangible characteristics of the service provision } \\
\hline Subcategories & Frequency & Evidence \\
\hline Positive aspects & 7 & $\begin{array}{l}\text { "Thanks TJDFT for the kindness on the service". } \\
\text { "I was surprised with the infrastructure created and the methodology to help the solution } \\
\text { of the conflicts. I did not have this perception of the Court System and I felt welcomed, } \\
\text { which changed my understanding of the service". }\end{array}$ \\
\hline Critical aspects & 12 & $\begin{array}{l}\text { "Having people that can help us to make the first entry and request of the legal process". } \\
\text { "Setting the mediation dates could be faster". } \\
\text { "Accessibility for disabled people". } \\
\text { "Improve the access of the CEJUSC". }\end{array}$ \\
\hline \multicolumn{3}{|r|}{ Category: Mediation results } \\
\hline Subcategories & Frequency & Evidence \\
\hline \multicolumn{3}{|r|}{ Positive Aspects } \\
\hline General & 24 & $\begin{array}{l}\text { "A good process, fast and efficient". } \\
\text { "Excellent job. A lot of effort and competence! Congratulations". } \\
\text { "Since the first contact by phone until the mediation session itself, everything was great". }\end{array}$ \\
\hline For the citizen & 13 & $\begin{array}{l}\text { "I really enjoyed the mediation, even though my case was not solved with a settlement. I } \\
\text { hope this service can help do solve other conflicts". } \\
\text { "This tool is of great interest to the population by abbreviating and solving conflicts". }\end{array}$ \\
\hline For the Court & 8 & $\begin{array}{l}\text { "I think it is a way to expedite legal processes in the justice system". } \\
\text { "This is the most efficient measure that the Court could adopt. Everyone is doing a great } \\
\text { job". }\end{array}$ \\
\hline \multicolumn{3}{|r|}{ Critical aspects } \\
\hline General & 1 & "Lacks effectiveness" \\
\hline For the citizen & 1 & $\begin{array}{l}\text { "In legal processes where one of the parties is a big company and the other is an } \\
\text { individual, there is little chance of success". }\end{array}$ \\
\hline For the Court & 2 & $\begin{array}{l}\text { "In my opinion, it would be important to keep a team in court to facilitate the } \\
\text { communication between debtor and creditor". }\end{array}$ \\
\hline
\end{tabular}

Source: Field research.

\section{DISCUSSION}

The discussion is structured as follows. First, the results of the exploratory and descriptive analysis are commented on. Then the results of the causal research and empirical models are discussed according to the objectives and hypotheses of the study.

The first specific objective, to test the validity of the USI created by the TJDFT, was addressed with descriptive statistics and exploratory factor analysis, which demonstrated internal correlation among the variables in each factor. The results show that the items of the USI are, mostly, well correlated, but that the items developed to measure the perceptions of co-production and the results for the citizens need to be reviewed so they can measure the results of the service in a more articulate and integrated way. The evaluation of the satisfaction with public services is more complex due to the 
specific characteristics of this sector, considering that some results can please some stakeholders while displeasing others (Kelly, 2005). Therefore, the review of the USI can help to better coordinate the measures of citizen satisfaction with management efforts to improve service provision (Kelly, 2005).

The second specific objective, to test, empirically, the relationship between the perception of coproduction, the competence of the mediator, the tangible and intangible characteristics of the service and the results of the judicial mediation for service users, was achieved through logistic regression and content analysis. These results are based in the first model that predicted the values of the dependent variable $[\mathrm{YC}]$ from one or more independent variables $[\mathrm{C}]-[\mathrm{C}]-[\mathrm{T}]$.

The results indicate that the independent variable, Competence of the mediator $[\mathrm{C}]$, was statistically significantly related to the dependent variable, Results for the citizen [YC] in four of the five models tested, being the only variable that stayed in the models. The four models where it was significant were the total model, civil, claimants and defendants.

In this sense, only $\mathrm{H} 1$ can be confirmed, namely that a positive perception of mediator competence increases the probability of a positive perception of the results of the judicial mediation for service users. This is an interesting result, because the variables that did not stay in the tested models $(C, T)$ are important for service delivery (Gallouj, 2007) and are highly appreciated by litigants in the descriptive analysis. In addition, the mediation service needs co-production between the parties involved so a consensual settlement can be reached, hence further investigation might be needed to complement these results.

About the variable [C'], as presented in the results of the exploratory factor analysis, judicial mediation is a complex process, in which the litigant parties present conflicting expectations about its results. This hampers the perception of co-production of satisfaction with the service provided. Due to the scope of the research, it was not possible to investigate other factors that may have contributed to this result, yet it could be inferred that aspects related to cultural elements, such as the "sentence culture" as well as the formation and characteristics of the brazilian culture might help explain these results. It is also important to stress that the items tested by the USI do not measure the impact of co-production on the results of the service, but instead they measure cooperation, in the sense of understanding of the needs of the parties involved. For this reason, the results were positive in the descriptive analysis but did not influence the perception of value of the citizens regarding the results delivered by the service.

It is also worth mentioning that the research is based on the Integrative Approach of innovation in which there is no distinction between product and service, but rather an integration of both. That said, the results for variable [C '] infer that if judicial mediation is understood by the user only as' process innovation' with respect to the physical and procedural space of negotiation (mediation) and 'product innovation' as a result of the lawsuit, whether favorable or unfavorable, there is a loss in the user's perception of the utility's of servisse. Thus, when the user cannot perceive the integration of the process and the final product / result, their perception of the change in behavior generated by innovation is impaired (Halvorsen et al., 2005).

The variable $[\mathrm{C}]$ is the only one that remained in the models tested. It can be inferred from this result that the mediator has a fundamental role in the judicial mediation session, once the litigant parties are worn out from the conflict they are trying to solve. Gallouj and Savona (2009) emphasize 
that the competence of the service provider, when dealing with the public sector, go beyond technical abilities, since the competence of the user of the services is often not well developed due to cognitive or economic struggle. The litigant parties perceive the conflict as an opportunity when the mediator is prepared, skillful, technically supported and using a non-adversarial approach that values emotions and reactions, allowing the parties to change their perception of the situation (Mello \& Baptista, 2011). For that reason, the public service provider should act on the basis of social and civic competence, in the case of the mediator, providing an environment that favors conversation. According to the Judicial Mediation Manual, in cases where the parties are worn out by the conflict and cannot engage by themselves in cooperative dialogue, they end up engaging in competitive and counter-productive situations. In these cases, the mediator has the role of assisting them to find more efficient solutions for the matters being discussed (Azevedo, 2015).

The content analysis showed that perception of co-production is strongly related to mediator competence and that mediator competence influences user satisfaction directly. This reinforces the results found in the logistic regression and explains co-production as an interaction between service provider and user. Some excerpts of the content analysis, in the category of Co-production with the mediator/service provider, reaffirms this statement. The litigant parties need the mediator to produce positive results in the judicial mediation.

The third specific objective, to test, empirically, the relationship between the perception of co-production, competence of the mediator, tangible and intangible characteristics of the service provision, and results of the judicial mediation for the service users and the results of the judicial mediation for the court, was addressed with the logistic regression based on the Model 2 and content analysis.

The results show that the independent variable Competence of the mediator $[\mathrm{C}]$ is statistically significant in all of the tested models, being the only variable that remained in the models. Thus, $\mathrm{H} 2$ was confirmed, that a positive perception of mediator competence increases the probability of a positive perception of the results for the Court. The results for the model dealing with family cases indicated that if the competence of the mediator are perceived as positive, the likelihood of a positive perception of the results increases by $4.16[\operatorname{Exp}(\mathrm{B})]$ times. Civil suits are $56.4 \%$ of the sample, while family suits account for the other $43.6 \%$. Thus, the competence of the mediator can have a positive and meaningful influence the perceptions of the Court in family mediations. This result underlines the importance of the mediator in enabling the parties to reach satisfactory outcomes.

Finally, the data indicates that, according to the perception of the parties involved, the competence of the mediator is critical for the results of the service, not only for users, but also for the Court. This result emphasizes the need to invest in the training and development of mediators, so they can conduct the process in the best way possible, helping the parties to reach positive outcomes and to re-establish a line of communication.

\section{CONCLUSION AND RECOMENDATIONS}

From the results and the discussion presented in the previous sections, even though judicial mediation is a highly co-produced process, the co-production variable did not remain in any of the empirical models. For this reason, Hypotheses 3 and 4 were not confirmed. It is possible to infer that this result 
was due to the complexity of the cases and legal processes that end up in mediation, which makes it hard for the litigant parties to notice the cooperation that occurs to reach an outcome. It is also the case that the items that make up the variable in the logistic regression measure cooperation between the parties in the process, not necessarily cooperation in producing the results. A review of the items used to measure co-production would appear desirable, so the results can be articulated with the other constructs investigated.

Hypotheses H5, H6 and $\mathrm{H} 7$ also did not remain in the empirical models, it is argued that the user does not correlate the results of the service provision with the material and immaterial technical characteristics. The content analysis shows that for users the material and immaterial technical characteristics are related to the attendance before and during the mediation session, the quality of the space, and the location of the forums and not the result of the service. Regarding H7, it is worth noting that in the exploratory factor analysis the factor that suffered the most alterations was the Results for the Citizen, in which of the eight items proposed in the theoretical classification, only two remained in the factor. PSU items that measure "results" so that they can be rewritten in a more articulate way.

Another result of this study is that the competence of the mediator increases the probability of a positive perception of the judicial mediation results for the service users and for the Court. For the citizen, the mediator is mainly responsible not only for steering the mediation process, but also for the outcomes obtained. The more effective the mediator's performance, the better the service is seen to be. Co-production is perceived to happen through the performance of the mediator, and it would be helpful to include items in the USI that measure this relationship and its impact on the service results.

The evaluation of user satisfaction with public services can provide managers with ways to improve the service. This research contributes to the further development of the study of the variables investigated, finding a correlation between the competence of the service provider and the results of the services for both the citizen and the organization. Although the variable co-production did not remain in any of the tested models, the researchers advance the suggestion that the influence of co-production is felt through the performance of the mediator. This research also contributes to the development of knowledge related to this field of study and its relationships with other constructs, and provides options for the improvement of the USI applied by the TJDFT. User evaluation can express the efficiency of a public service (Kelly, 2005), reaching social well-being. In this way, the data obtained in this study can open up new possibilities for the measurement of service user satisfaction in judicial mediation.

This study has some limitations, particularly in relation to (a) the limited potential for generalizing the results, as the study refers only to the TJDFT and each court has autonomy to evaluate its services in any way it sees fit; (b) the lack of human resources may have affected the transcription of the data to the data bank, so it would be beneficial to have a team in Court responsible for the USI; (c) the gaps in the literature and empirical studies made it more difficult to connect and explain the results found; (d) the study relied heavily on secondary data, which requires commitment from the researcher to address the data academically and with theoretical and empirical grounds.

From the data gathered and the results obtained, the researchers conclude that further research could: (a) compare the results found in the judicial mediation data bank with the judicial conciliation results, to analyze and compare the correlations; (b) apply the USI in other courts to investigate and 
RAP | Innovation in justice: co-production, competence and user satisfaction in judicial mediation

compare the results; (c) test the results found in this study considering the perceptions of user coproduction based on the competence of the mediator; (d) analyze the impacts of Brazilian cultural formation on the results of judicial mediations as well as other co-produced public services. Such further research could develop this field of study. Finally, in general, future research on innovation and co-production should focus on studies that aim for the expansion, evaluation and refinement of the field, producing increasingly consistent results. 


\section{REFERENCES}

Albury, D. (January, 2005). Fostering Innovation in Public Services. Public Money and Management, 25(1), 51-56.

Azevedo, G. (2015). Manual de Mediação Judicial. Brasília, DF: Ministério da Justiça e PNUD.

Bardin, L. (2009). Análise de conteúdo. Lisboa, Portugal: Edições 70 LDA.

Brudney, L., \& England, E. (1983). Toward a definition of the coproduction concept. Public Administration Review, 43(1), 59-65.

Chen, J., Tsou, H., \& Ching, R. (2011). Coproduction and its effects on service innovation. Industrial Marketing Management, 40, 1331-1346.

Court of Justice of the Federal District and Territories. (2013). Pesquisa de satisfação do usuário: Construção e Implantação no TJDFT. Brasília, DF. Retrieved from http://migre.me/tEWkz

Djellal, F., Galouj, F., \& Miles, I. (2013). Two decades of research on innovation in services: which place for public services? Structural Change and Economic Dynamics, 27, 98-117.

Field, A. (2009). Descobrindo a estatística usando o SPSS. Porto Alegre, RS: Bookman e Artmed.

Fleury, M. T. L., \& Fleury, A. (2001). Construindo o conceito de competência. Revista de administração contemporânea, 5(SPE), 183-196.

Gallouj, F. (2002). Innovation in services and the attendant old and new myths. Journal of SocioEconomics, 31, 137-154.

Gallouj, F. (2007). Economia da inovação: um balanço dos debates recentes. In R. Bernardes, \& T. Andreassi (Orgs.), Inovação em serviços intensivos em conhecimento. São Paulo, SP: Saraiva.

Gallouj, F., \& Savona, M. (2009). Innovation in services: a review of the debate and the research agenda. Journal of Evolutionary Economics, 19(2), 149-172.

Gallouj, F., \& Savona, M. (2010). Towards a theory of innovation in services: a state of the art. In: F. Gallouj, \& F. Djellal (Eds.), The Handbook of Innovation and Services (pp. 27-48). Massachussets, USA: Edward Elgar Publishing Limited.
Gallouj, F., \& Weinstein, O. (1997). Innovation in services. Research Policy, 26, 537-556.

Hair, J. F., Black, W. C., Babin, B. J., Anderson, R. E., \& Tatham, R. L. (2009). Análise multivariada de dados. Porto Alegre, RS: Bookman.

Halvorsen, T., Hauknes, J., Miles, I., \& Roste, R. (2005). On the differences between Public and Private Sector Innovation. Oslo, Norway: NIFU STEP.

Hauknes, J. (1998). Innovation in the service economy. Oslo, Norway: STEP Rapport.

Hertog, P. D. (2000). Knowledge-intensive business services as co-producers of innovation. International Journal of Innovation Management, 4(04), 491-528.

Kelly, J. M. (2005). The dilemma of the unsatisfied customer in a market model of public administration. Public Administration Review, 65(1), 76-84.

Koch, P., \& Hauknes, J. (2005). On Innovation in the Public Sector. (Publin Report D20). Oslo, Norway: NIFU STEP.

Law 13.140, of 26 of june of 2015. (2015). Brasília. Retrieved from http://www.planalto.gov.br/ ccivil_03/_Ato2015-2018/2015/Lei/L13140.htm

Lusch, R. F., Vargo, S. L., \& O’Brien, M. (2007). Competing through service: Insights from servicedominant logic. Journal of retailing, 83(1), 5-18.

Mello, K. S. S., \& Baptista, B. G. L. (2011). Mediação e conciliação no judiciário: dilemas e significados. Dilemas: Revista de Estudos de Conflito e Controle Social, 4(1), 97-122.

Morais Sales, L. M., \& Chaves, E. C. C. (2014). Mediação e conciliação judicial: a importância da capacitação e de seus desafios. Seqüência: estudos jurídicos e políticos, 35(69), 255-280.

Mustak, M., Jaakkola, E., \& Halinen, A. (2013). Customer participation and value creation: a systematic review and research implications. Managing Service Quality: An International Journal, 23(4), 341-359.

Osborne, S. P. (2013). A services-influenced approach to public service innovation?. In Osborne, S. P., \& Brown, L. (Eds.). Handbook of innovation in public services. Cheltenham, UK - Northampton, MA, USA: Edward Edgar. 
Ostrom, A. L., Bitner, M. J., Brown, S. W., Burkhard, K. A., Goul, M., Smith-Daniels, V. \& Rabinovich, E. (2010). Moving forward and making a difference: research priorities for the science of service. Journal of Service Research, 13(1), 4-36.

Ottmann, G., Laragy, C., Allen, J., \& Feldman, P. (2011). Coproduction in practice: participatory action research to develop a model of community aged care. Systemic practice and action research, 24(5), 413-427.

Passani, A., Corrêa, M. G., \& Bastos, S. (2014). Resolução de Conflitos para representantes de Empresas. Brasília, DF: CEAD/UnB.

Resolution n. 125, of 29 of november of 2010. (2010). Brasília, DF. 2010. Retrieved from http://www.cnj.jus. br/atos-administrativos/atos-da-presidencia/323resolucoes/12243-resolucao-no-125-de-29\%20\%20 -de-novembro-de-2010

Sadek, M. T. A. (May, 2004). Judiciário: perspectivas de reforma. Revista Opinião Pública, 10(1), 01-62.

Shim, J. T., Sheu, T. S., Chen, H. G., Jiang, J. J., \& Klein, G. (2010). Coproduction in successful software development projects. Information and Software Technology, 52(10), 1062-1068.

Sousa, M.M, \& Guimarães, T. A. (2014). Inovação e desempenho na administração judicial: desvendando lacunas conceituais e metodológicas. Revista de Administração e Inovação, 11(2), 321-344.

Stumpf, J. C. (2009). Judiciário: morosidade e inovação. Porto Alegre, RS: Tribunal de Justiça do Estado do Rio Grande do Sul, Departamento de Artes Gráficas.
Sundbo, J., \& Gallouj, F. (1998). Innovation in services. (SI4S Synthesis Paper, n.2). Oslo, Norway: STEP.

Tabachnick, B. G., \& Fidell, L. S. (2001). Using multivariate statistics. London, England, Pearson.

Torfing, J. (2013). Collaborative innovation in the public sector. In S. P. Osborne, \& L. Brown (Eds.), Handbook of innovation in public services. Cheltenham, UK - Northampton, MA, USA: Edward Edgar.

Vargas, L. D. (2006). Julgados de Paz e Mediação: uma nova face da Justiça. Almedina, Portugal: Coimbra.

Vargo, S. L., \& Lusch, R. F. (January, 2004). Evolving to a new dominant logic for marketing. Journal of Marketing, 68, p. 1-17.

Vieira, J. L., \& Pinheiro I. A. (2008). Contribuições do Conselho Nacional de Justiça para a Gestão do Judiciário. In: Encontro ANPAD, 32, 2008, Rio de Janeiro. Rio de Janeiro: ANPAD.

Warat, L. A. O ofício do mediador. Florianópolis, SC: Habitus, 2001. v. 1.

Watanabe, K. (2005). Cultura da Sentença e Cultura da Pacificação. In: F. L. Yarchell, \& M. Z. Moraes (Org.), Estudos em Homenagem à Professora Ada Pellegrini Grinover, São Paulo, SP: DPJ.

Zainuddin, N., Russell-Bennett, R., \& Previte, J. (2013). The value of health and wellbeing: an empirical model of value creation in social marketing. European Journal of Marketing, 47(9), 1504-1524. 


\section{Janaina Angelina Teixeira}

https://orcid.org/0000-0001-7238-0709

PhD Student in Education at the Graduate Program in Education at the University of Brasília (UnB); Professor at the Secretary of Education of Federal District. E-mail: janaina.angelina@gmail.com

\section{Mariana Carolina Barbosa Rêgo}

https://orcid.org/0000-0002-6939-5130

$\mathrm{PhD}$ in Business Administration, Graduate Program in Business Administration, University of Brasilia (UnB); Professor at the Federal Institute of Brasilia (IFB). E-mail: marianaacarolina@gmail.com

\section{Antonio Isidro da Silva Filho}

iD

https://orcid.org/0000-0003-1174-8586

$\mathrm{PhD}$ in Business Administration from the University of Brasilia (UnB); Professor at the Graduate Program in Administration at the University of Brasilia (UnB). E-mail: antonio.isidro.filho@gmail.com 